University of Nebraska - Lincoln

DigitalCommons@University of Nebraska - Lincoln

$4-1988$

\title{
Population Dynamics of Distoichometra bufonis (Cestoda: Nematotaeniidae) in Bufo woodhousii
}

John J. Janovy Jr.

University of Nebraska - Lincoln, jjanovy1@unl.edu

Eugene Lee Hardin

Women's Health Care of Western Colorado

Follow this and additional works at: https://digitalcommons.unl.edu/bioscijanovy

Part of the Parasitology Commons

Janovy, John J. Jr. and Hardin, Eugene Lee, "Population Dynamics of Distoichometra bufonis (Cestoda: Nematotaeniidae) in Bufo woodhousii" (1988). John Janovy Publications. 18.

https://digitalcommons.unl.edu/bioscijanovy/18

This Article is brought to you for free and open access by the Papers in the Biological Sciences at DigitalCommons@University of Nebraska - Lincoln. It has been accepted for inclusion in John Janovy Publications by an authorized administrator of DigitalCommons@University of Nebraska - Lincoln. 


\title{
POPULATION DYNAMICS OF DISTOICHOMETRA BUFONIS (CESTODA: NEMATOTAENIIDAE) IN BUFO WOODHOUSII
}

\author{
E. L. Hardin and J. Janovy, Jr. \\ School of Biological Sciences, University of Nebraska-Lincoln, Lincoln, Nebraska 68588-0118
}

\begin{abstract}
Prevalence, density, and variance/mean (=variance/density) ratios are reported for the cestode Distoichometra bufonis in 28 samples of the amphibian host, Bufo woodhousii, taken over a 3-yr period at 2 study sites on the South Platte River in Keith County, Nebraska, U.S.A. In addition, changes in host demography resulting from entry of newly metamorphosed toads into the terrestrial population are given. Prevalence and density (average number of worms per host, infected + noninfected) did not vary significantly either within or between sites and years unless newly metamorphosed toads were included in the analysis. Prevalence ranged from 70 to $100 \%$, and density from 2.7 to 14.8 worms per host, excluding samples containing newly metamorphosed toads. The bulk of metamorphosis occurred in late June or early July, and by August both prevalence and density had returned to their premetamorphosis values. The host/parasite system is interpreted as one in which disruption of the host population's demographic makeup only temporarily perturbs parasite population structure.
\end{abstract}

The Rocky Mountain toad, Bufo woodhousii Girard, 1854, occurs throughout most of Nebraska. Casual observations from 1976 to 1983 suggested that the toad had a relatively short breeding season in western Nebraska (late May and June), that breeding took place in ephemeral ponds on a schedule that produced a rather synchronous influx of newly metamorphosed individuals into the terrestrial population, usually in early July, and that prevalence of the nematotaeniid cestode, Distoichometra bufonis Dickey, 1921, was quite high. The studies reported here were done in an attempt to describe some of the population level interactions between the toads and these cestodes.

As a resource for $D$. bufonis, B. woodhousii presents 2 interesting problems: (1) physically, the host is a patchy and ephemeral resource in the sense of Price (1980), especially because the toads are in a state of torpor during the winter, and (2) the host population is disrupted demographically with the influx of newly metamorphosed toads, a perturbation that alters the resources available to the parasites. Thus, even though the life cycle of $D$. bufonis is not known, parasite population dynamics should reveal, in part, the manner in which the worm population structure is maintained in nature. The study was conducted by attempting to answer the following specific questions: (1) Does the demographic makeup of the host population change over the course of the active season? (2) In what manner are the parasites distributed among the hosts? (3)

Received 23 November 1987; revised 3 February 1988; accepted 7 February 1988.
Are the observed parasite distributions consistent between years and sites? (4) At what stage in the host's life does it become infected? (5) Are the hosts exposed to infections throughout the active season? (6) Does there exist a relationship between parasite density and prevalence, and host size (approximate measure of age) and sex? And (7) does the parasite overwinter in the definitive host?

\section{MATERIALS AND METHODS}

The host species was identified as Bufo woodhousii using Ballinger and Lynch (1983). Tadpole specimens were identified using larval Bufo characters of Wright and Wright (1949) and identification of toads produced from these tadpoles. The parasite species was identified as $D$. bufonis using original descriptions by Dickey (1921) and of D. kozloffi by Douglas (1958), as well as D. bufonis types borrowed from the USNM Helminthological Collection, Beltsville, Maryland, and Nebraska specimens borrowed from the $\mathbf{H}$. W. Manter Laboratory, University of Nebraska State Museum.

\section{Study sites}

Two sites were used, both near the South Platte River in Keith County, Nebraska. The river generally flows at capacity in the spring due to snowmelt runoff. During May and early June, receding waters and spring rains contribute to the formation of ephemeral ponds, the main breeding habitat of $B$. woodhousii. The primary study site used from 1984 to 1986 was a rectangle 300 $\times 500 \mathrm{~m}$, near an abandoned gravel pit $4 \mathrm{~km}$ east of the town of Roscoe, Nebraska. A second site, chosen for its similarity to the Roscoe one, was $1 \mathrm{~km}$ south of Brule, Nebraska, and was used in 1986. One site, and the year it was used, is defined as a site-year; the study thus covered 4 site-years (Table I).

\section{Sampling}

The breeding of $B$. woodhousii near the South Platte River is relatively synchronous. Toads mate in late May and early June and most tadpoles metamorphose 
during a 2- or 3-wk period in late June or early July. Collecting began in mid-April except in 1984 when it began in June, and ended in late September or early October. Adult toads were collected biweekly at each study site over the course of the active season. Tadpoles were sampled once a week when available.

Hosts were taken to the Cedar Point Biological Station $13 \mathrm{~km}$ north of Ogallala, Nebraska, and dissected within $24 \mathrm{hr}$ of capture. Snout/vent length (SVL) and sex of each toad were recorded. Number of worms per individual host was determined by scolex count. All tissues of tadpoles were examined for parasites.

Recruitment rates were measured by use of sentinal toads and mark-recapture studies. In the sentinal study, during 1985, 200 newly metamorphosed toads (16-21 $\mathrm{mm}$ SVL) were collected from the north shore of Lake McConaughy in an area in which no adults were found to be infected with $D$. bufonis. Sixty toads were dissected to ensure the population was initially uninfected. The remaining 140 toads were split into 2 groups of 70 and each group placed in an $18-\mathrm{m}^{2}$ enclosure that had been cleared of indigenous toads, on the banks of an ephemeral pond, in the study site. Both groups were exposed to the area of natural transmission for $2 \mathrm{hr}$ in the early evening. One group was returned for additional 2-hr periods on 6 consecutive days, for a total of $14 \mathrm{hr}$ of exposure. The stomach contents of 5 toads from each group were collected by dissection on site and saved in $70 \%$ ethanol. In the mark-recapture study in 1986,170 adult toads of various sizes were collected from the north shore of Lake McConaughy. Fifty were dissected to confirm that the group did not harbor $D$. bufonis. The remaining 120 were toe-clipped and released at Roscoe on 28 July. Marked toads were recaptured on 4 August and 18 August. In both studies, recruitment rates were expressed as number of worms acquired per toad per unit time exposure. A cohort from the original host population was dissected after the studies to ensure the toads were still free of $D$. bufonis.

Attempts to find $B$. woodhousii in the winter were unsuccessful. However, 6 toads from the Roscoe site were determined to be infected by the presence of $D$. bufonis proglottids, parauterine organs, and egg capsules in the feces. These toads were then placed in moist sand in an aquarium, which was put into a refrigerator whose temperature was cooled to $4 \mathrm{C}$ over a $24-\mathrm{hr}$ period. Six weeks later the aquarium was removed and the toads examined for worms.

\section{Statistical analysis}

Young-of-the-year, second-year, and older-than-second-year groups were established from SVL distributions, with $65 \mathrm{~mm}$ being chosen as the point separating the latter 2 groups. This choice was based on measurements from 1985 and 1986. In the first sample from each site, no toads between 57 and $66 \mathrm{~mm}$ were found, whereas numerous toads between 39 and 57 $\mathrm{mm}$, and greater than $66 \mathrm{~mm}$ SVL were collected.

Density and variance/density ratios were analyzed by the methods of Taylor et al. (1978). Contingency table analysis was used to determine if prevalence was independent of host sex and size. Relationships between infrapopulations and host size were determined from regression lines using SVL and number of worms
TABLE I. Sampling data and parasite distribution parameters for $\mathrm{D}$. bufonis in $\mathrm{B}$. woodhousii.

\begin{tabular}{|c|c|c|c|c|c|c|}
\hline $\begin{array}{l}\text { Site- } \\
\text { year }\end{array}$ & $\begin{array}{c}\text { Sample } \\
\text { date }\end{array}$ & $\mathbf{n}$ & $\begin{array}{l}\text { Mean } \\
\text { SVL }\end{array}$ & $\begin{array}{l}\text { Prev- } \\
\text { alence } \\
(\%)\end{array}$ & Density & $\begin{array}{c}\text { Vari- } \\
\text { ance/ } \\
\text { density }\end{array}$ \\
\hline \multirow{7}{*}{$\begin{array}{c}\text { Roscoe, } \\
1984\end{array}$} & $6 / 20^{*}$ & 7 & 35.4 & 57 & 4.0 & 5.8 \\
\hline & $7 / 06$ & 14 & 41.1 & 79 & 6.1 & 6.4 \\
\hline & $7 / 16$ & 12 & 44.0 & 75 & 9.6 & 7.7 \\
\hline & $7 / 30$ & 14 & 39.7 & 100 & 11.9 & 5.5 \\
\hline & $8 / 14$ & 10 & 50.8 & 100 & 10.8 & 6.6 \\
\hline & $8 / 22$ & 8 & 44.8 & 100 & 11.9 & 4.4 \\
\hline & $9 / 12$ & 11 & 46.7 & 91 & 9.7 & 3.3 \\
\hline \multirow{9}{*}{$\begin{array}{c}\text { Roscoe, } \\
1985\end{array}$} & $5 / 08$ & 20 & 47.1 & 70 & 6.2 & 5.9 \\
\hline & $5 / 28$ & 16 & 46.8 & 81 & 7.4 & 7.4 \\
\hline & $6 / 11$ & 14 & 49.9 & 71 & 2.7 & 2.7 \\
\hline & $6 / 24$ & 10 & 53.6 & 100 & 6.1 & 3.7 \\
\hline & $7 / 07^{*}$ & 10 & 37.9 & 80 & 6.2 & 5.4 \\
\hline & $7 / 20$ & 15 & 33.3 & 53 & 3.9 & 4.9 \\
\hline & $8 / 02$ & 11 & 35.2 & 91 & 6.2 & 2.7 \\
\hline & $8 / 16$ & 9 & 37.9 & 89 & 14.8 & 8.8 \\
\hline & $9 / 15$ & 15 & 45.6 & 73 & 8.3 & 5.9 \\
\hline \multirow{6}{*}{$\begin{array}{c}\text { Roscoe } \\
1986\end{array}$} & $5 / 12$ & 16 & 65.6 & 100 & 10.8 & 8.2 \\
\hline & $6 / 02$ & 20 & 54.7 & 90 & 5.7 & 3.0 \\
\hline & $6 / 19$ & 16 & 67.1 & 82 & 6.1 & 7.2 \\
\hline & $7 / 05^{*}$ & 24 & 36.8 & 46 & 2.3 & 5.0 \\
\hline & $7 / 26$ & 40 & 29.8 & 40 & 1.8 & 5.5 \\
\hline & $8 / 18$ & 20 & 38.3 & 85 & 4.5 & 3.3 \\
\hline \multirow{6}{*}{$\begin{array}{l}\text { Brule, } \\
1986\end{array}$} & $5 / 14$ & 22 & 50.7 & 86 & 4.4 & 3.4 \\
\hline & $6 / 01$ & 20 & 48.9 & 75 & 4.6 & 3.8 \\
\hline & $6 / 23$ & 18 & 57.9 & 78 & 4.2 & 3.0 \\
\hline & $7 / 05^{*}$ & 25 & 30.5 & 28 & 1.6 & 7.2 \\
\hline & $7 / 27$ & 40 & 37.0 & 45 & 1.9 & 3.6 \\
\hline & $8 / 16$ & 20 & 38.5 & 85 & 6.3 & 6.5 \\
\hline
\end{tabular}

* Sample dates on which newly metamorphosed toads first appeared in the terrestrial population.

for the total collection and demographic subgroups. Differences between samples within site-years, and between site-years, were analyzed by means of the Kruskal-Wallis nonparametric method (Sokal and Rohlf, 1981) using infrapopulations as the observations to be ranked.

Terminology is consistent with that recommended by Margolis et al. (1982). Density is defined as the average number of worms per toad (infected + noninfected) in a sample.

\section{RESULTS}

Collection dates, sample sizes, mean host SVL, worm prevalences, densities, and variance/density ratios are given in Table I. No toads were collected on trips to Roscoe in 1985 and 1986, and to Brule in 1986, prior to the first samples listed, or on trips to the study sites $3 \mathrm{wk}$ after the last sample of each site-year. The annual drop in SVL seen in Table I was due to metamorphosis of tadpoles. Roscoe, in 1984, did not include premetamorphosis toads, but the slow increase in SVL was similar to that of postmetamorphosis samples in other years. 
TABLE II. Relationships between snout/vent length and D. bufonis infrapopulations.

\begin{tabular}{|c|c|c|c|c|c|c|c|c|}
\hline Site-year & Group & Slope & Y-intercept & $r$ & $\begin{array}{l}\text { Variance } \\
\text { due to } \\
\text { regression }\end{array}$ & $\begin{array}{l}\text { Variance } \\
\text { about } \\
\text { regression }\end{array}$ & $F$ & df \\
\hline $\begin{array}{r}\text { Roscoe, } \\
1984\end{array}$ & $\begin{array}{c}\text { first yr } \\
\text { second yr }+\end{array}$ & $\begin{array}{r}0.41 \\
-0.15\end{array}$ & $\begin{array}{r}-1.84 \\
15.89\end{array}$ & $\begin{array}{r}0.34^{*} \\
-0.32^{*}\end{array}$ & $\begin{array}{r}331.41 \\
99.95\end{array}$ & $\begin{array}{l}64.76 \\
26.90\end{array}$ & $\begin{array}{l}5.12 \dagger \\
3.72\end{array}$ & $\begin{array}{l}1,41 \\
1,31\end{array}$ \\
\hline $\begin{array}{c}\text { Roscoe, } \\
1985\end{array}$ & $\begin{array}{c}\text { first yr } \\
\text { second yr }+\end{array}$ & $\begin{array}{r}0.37 \\
-0.08\end{array}$ & $\begin{array}{r}-4.82 \\
9.79\end{array}$ & $\begin{array}{c}0.31^{*} \\
-0.15\end{array}$ & $\begin{array}{r}268.88 \\
53.31\end{array}$ & $\begin{array}{l}54.30 \\
33.91\end{array}$ & $\begin{array}{l}4.95 \dagger \\
1.57\end{array}$ & $\begin{array}{l}1,47 \\
1,69\end{array}$ \\
\hline $\begin{array}{c}\text { Roscoe } \\
1986\end{array}$ & $\begin{array}{c}\text { first yr } \\
\text { second yr+ }\end{array}$ & $\begin{array}{l}0.15 \\
0.03\end{array}$ & $\begin{array}{r}-2.97 \\
5.44\end{array}$ & $\begin{array}{l}0.35^{*} \\
0.08\end{array}$ & $\begin{array}{l}75.75 \\
17.74\end{array}$ & $\begin{array}{r}7.71 \\
46.42\end{array}$ & $\begin{array}{l}9.82 \dagger \\
0.38\end{array}$ & $\begin{array}{l}1,72 \\
1,61\end{array}$ \\
\hline $\begin{array}{r}\text { Brule, } \\
1986\end{array}$ & $\begin{array}{c}\text { first yr } \\
\text { second } y r+\end{array}$ & $\begin{array}{r}0.21 \\
-0.05\end{array}$ & $\begin{array}{r}-3.61 \\
6.83\end{array}$ & $\begin{array}{c}0.39^{*} \\
-0.12\end{array}$ & $\begin{array}{r}213.56 \\
16.14\end{array}$ & $\begin{array}{l}16.84 \\
15.05\end{array}$ & $\begin{array}{c}12.68 \dagger \\
1.07\end{array}$ & $\begin{array}{l}1,72 \\
1,69\end{array}$ \\
\hline
\end{tabular}

* The probability of obtaining higher absolute $r$-values by chance alone if SVL is independent of infrapopulation is less than 0.05 .

$\dagger$ The probability of obtaining observed $F$-value by chance alone if variances are equal is less than 0.05 .

Parasite populations were overdispersed in all samples (Table I). Densities and prevalences were generally at their lowest during and shortly after the entry of newly metamorphosed toads into the terrestrial population, then approached those of the premetamorphosis period within a few weeks. Kruskal-Wallis analysis showed no difference in "density location" (see Sokal and Rohlf, 1981) for Roscoe, 1984, and Roscoe, 1985, samples, or for the 4 site-years when samples within site-years were combined. The 2 site-years for 1986 yielded an adjusted Kruskal-Wallis $H$-value high enough to reject the hypothesis of no difference between sample infrapopulations, but removal of the samples with newly metamorphosed toads reduced the adjusted $H$-value enough to accept the null hypothesis. Thus, the distribution of $D$. bufonis infrapopulations in toad samples was essentially the same for all collections unless, in some cases, a known alteration in the demographic makeup of the host population occurred. In such cases, removal of the heterogeneous samples allowed acceptance of the null hypothesis for all the remaining samples.

With the exception of newly metamorphosed toads, virtually all size classes of hosts were infected (Figs. 1, 2). However, the prevalence among 15-25-mm SVL toads depended somewhat on the year (Roscoe, 1984, 4/8 infected; Roscoe, 1985, 2/8; Roscoe, 1986, 10/34; Brule, 1986, $5 / 24)$. Thus, recruitment began within a few days after metamorphosis and continued during the first 2 mo of terrestrial life. Significant positive correlations were obtained between young-of-theyear SVL and infrapopulation, but similar results were not observed when older toads were included in the analysis or analyzed separately (Table II). Recruitment was probably not confined to the young of the year, however, because 6 larger toads were found with short translucent worms typical of those in small young-of-theyear hosts. Increases in density were accompanied by increasing overdispersion (Table III). Contingency table analysis showed prevalence to be independent of sex when all samples were combined. Prevalence was not independent of size, with the second-year toads being most frequently infected (Table IV).

In the recruitment experiments, no infections were found in small toads allowed to feed for 2 and $14 \mathrm{hr}$. The feeding rates were 5.8 and 5.1 prey items $/ \mathrm{hr} /$ toad for the 2 groups, respectively. In the mark-recapture study, 1 of 6 toads recovered $1 \mathrm{wk}$ after release was infected with 5 immature worms, and 3 additional toads recovered $3 \mathrm{wk}$ after release were all infected. The

TABLE III. Log variance/log density relationships in the $\mathrm{D}$. bufonis/B. woodhousii system.

\begin{tabular}{|c|c|c|c|c|c|c|c|}
\hline Site-year & Slope & $Y$-intercept & $r$ & $\begin{array}{l}\text { Variance } \\
\text { due to } \\
\text { regression }\end{array}$ & $\begin{array}{l}\text { Variance } \\
\text { about } \\
\text { regression }\end{array}$ & $F$ & df \\
\hline Roscoe, 1984 & 0.85 & 2.02 & 0.78 & 0.73 & 0.10 & 7.30 & 1,5 \\
\hline Roscoe, 1985 & 1.62 & 0.49 & 0.89 & 3.53 & 0.13 & 27.81 & 1,7 \\
\hline Roscoe, 1986 & 1.16 & 1.38 & 0.89 & 2.93 & 0.16 & 15.31 & 1,4 \\
\hline Brule, 1986 & 0.86 & 1.64 & 0.79 & 1.10 & 0.16 & $6.84^{*}$ & 1,4 \\
\hline
\end{tabular}

* The probability of obtaining the observed $F$-value by chance alone if variances are equal is less than 0.10 . For all other $F$-values the probability is less than 0.05. All $r$-values are high enough to reject the hypothesis that log variance is independent of log density, at the 0.05 level. 

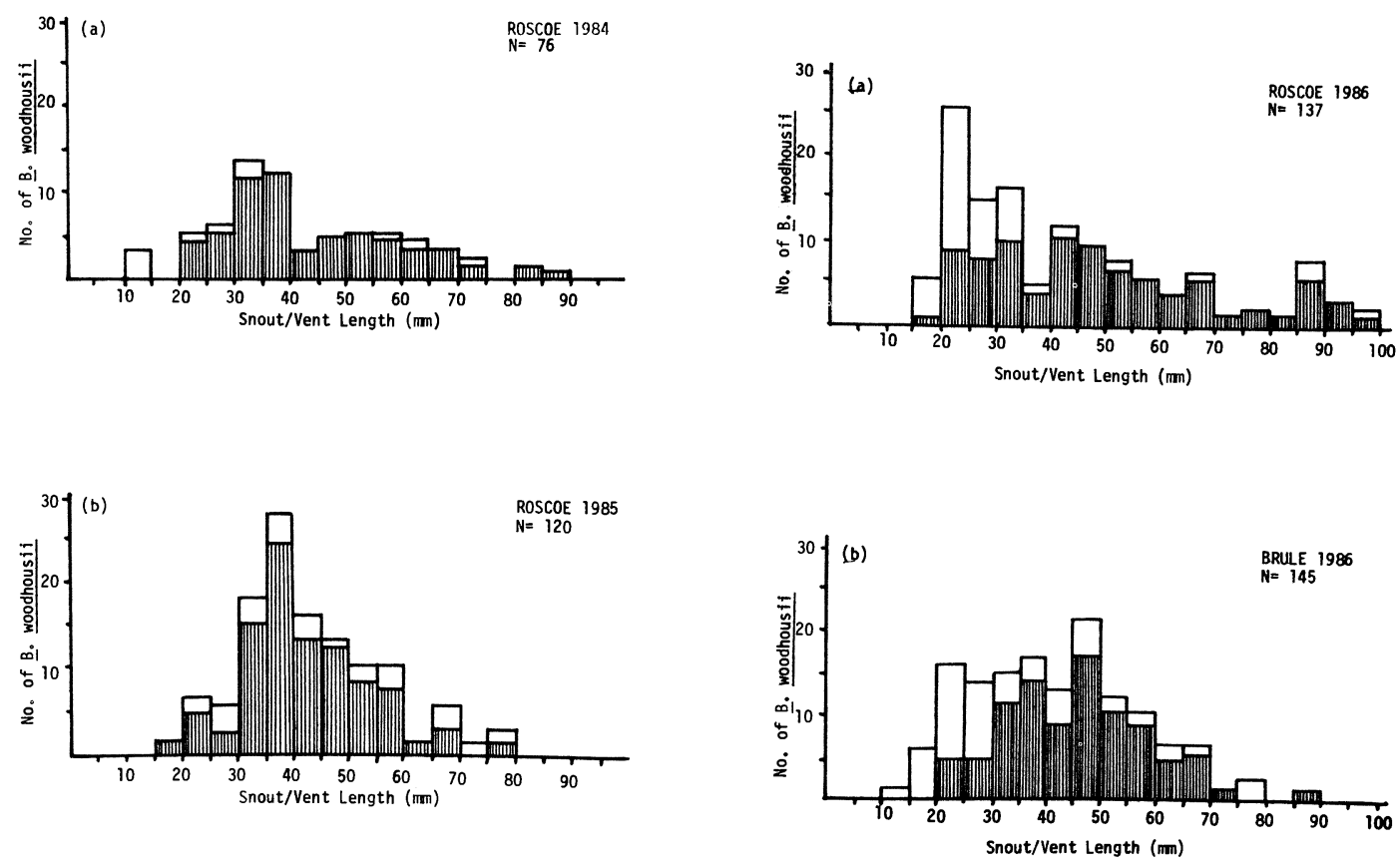

Figures 1, 2. Distribution of B. woodhousii by size for 4 site-years, and distribution of the infected subpopulations (shaded portions of the bars).

cohorts of these experimental animals, on the north shore of Lake McConaughy, remained free of worms.

Out of 400 tadpoles and 125 newly metamorphosed toads dissected, none were found to have worms either in the intestinal lumen or viscera.

All 6 toads refrigerated for $6 \mathrm{wk}$ were found to be infected with living $D$. bufonis, but some of the worms had evidently aborted their strobilae. The short worms were relatively opaque, unlike the translucent ones, of similar length, in young of the year.

\section{DISCUSSION}

The results suggest that a parasite's population structure, as described by distribution parameters, can be regulated in certain host/parasite systems in nature. Thus, in this natural experiment (see Diamond, 1986), the introduction of large numbers of uninfected toads into the host population produced only temporary changes in prevalence, density, or variance/density ratios in D. bufonis. The general stability of the parasite population is shown by the fact that over the 4 site-years, prevalence varied between 70 and $100 \%$, density between 3 and 15, and variance/ density ratios between 3 and 9 , when samples containing newly metamorphosed toads were excluded. Furthermore, the results of the KruskalWallis tests revealed no significant differences in "location" of infrapopulations between samples within years, and between years, again excluding the samples with newly metamorphosed toads.

Although the variations reported for density and prevalence may seem substantial, they include sampling error but are still within a single order of magnitude, unlike the population structure variation seen in some other systems sam-

TABLE IV. Contingency table analysis of prevalences by sex and age (estimated from $S V L$ ), of $\mathrm{D}$. bufonis infections in $\mathrm{B}$. woodhousii.

\begin{tabular}{lccc}
\hline \multicolumn{1}{c}{ Group } & $\begin{array}{c}\text { Number } \\
\text { infected }\end{array}$ & $\begin{array}{c}\text { Number } \\
\text { nonin- } \\
\text { fected }\end{array}$ & Chi-square \\
\hline Males & 99 & 17 & \\
Females & 105 & 26 & 1.15 \\
Young of the year & 141 & 98 & \\
Second year & 155 & 23 & $39.06^{*}$ \\
Second year & 155 & 23 & \\
Third year & 46 & 14 & 3.71 \\
Young of the year & 141 & 98 & \\
Third year & 46 & 14 & $6.39^{*}$ \\
\hline
\end{tabular}

* Chances of obtaining chi-value by chance alone less than 0.05 if frequency of infection is independent of compared demographic group. 
pled repeatedly. For example, Jarroll (1979) reported variance/mean ratios from 4.7 to 51.7 with Bothriocephalus rarus in newts, and Grimes and Miller (1976) reported ratios of 0.66-92.38 with Monobothrium ulmeri in Erimyzon oblongus. A number of other parasite species' populations exhibit density and variance/density ratios that fluctuate over 2 or more magnitudes (Lemly and Esch, 1984; Janovy and Hardin, 1987). In addition, prevalence is high during the toads' active season, which, along with the low and fairly stable density, suggests that most of the $D$. bufonis genetic variation is displayed against most of the heterogeneity provided by the definitive host. That is, parasites are not aggregated into a few host individuals. This basic feature of the relationship is achieved through rather indiscriminate transmission to young of the year coupled with an as yet unknown mechanism for limiting the truly heavy infections that are the basis for high variances in many other systems.

The slopes of regression lines describing the relationship between worm population distribution $\log$ density and $\log$ variance are about half those reported for some other host/parasite combinations. (Taylor et al. [1978]; Jarroll [1979], 2.8* for B. rarus in newts; Lemly and Esch [1984], $2.2^{*}$ for $U$. ambloplitis in sunfish; Janovy and Hardin [1987]; Riggs and Esch [1987], 2.3* and 3.8* for $B$. acheilognathi in 2 cyprinid species. $*$ = Slopes not actually given in the published paper, but calculated from data in the tables or figures.) This observation means that mechanisms that produce overdispersion in the $D . b u$ fonis/B. woodhousii system do not operate strongly to link increasing density with exponentially increasing variance.

The results provide definitive answers to most of the original questions, and in so doing, describe the parasite population's behavior that characterizes natural transmission. The infection is primarily one of first- and second-year toads, although that distribution may be as much of ecological as physiological origin, because the intermediate host, if present, is small enough to be eaten by a $20-\mathrm{mm}$ SVL toad, and eaten in fairly large numbers. For example, if the sentinel toad experiments can be extrapolated to the marked and recaptured toads, then an individual $B$. woodhousii consumes at least 4,000 prey items per cestode infection.

The life cycle of $D$. bufonis is unknown. Joyeux (1924) and Stumpf (1981/1982) both stated that the life cycle was direct in Cylindrotaenia sp., a related nematotaeniid. Prudhoe and Bray (1982) did not find the Joyeux (1924) work completely convincing, and our own efforts to repeat the Stumpf (1981/1982) experiments were not successful. No infections were produced in newly emerged toads, Tenebrio molitor, or Periplaneta americana force-fed proglottids, although egg capsules could be found in the intestine. Nor could ingested eggs be found in the guts of labraised Tribolium confusum, or wild-caught carabids (2 species) or staphylinids (frequent prey items for small B. woodhousii) exposed to macerated proglottids on moist filter paper. Although these experiments were not exhaustive, their failure suggests that the problem of nematotaeniid life cycles is far from being solved.

However, the life cycle is not only easily completed under suitable ecological conditions in nature, it is just as easily interrupted for long periods by unsuitable conditions. The latter is shown by the persistence of noninfected $B$. woodhousii populations on the north shore of Lake McConaughy (Keith County, Nebraska). The breeding biology of $B$. woodhousil, and by inference that of other species, as well as the ecological circumstances under which they exist at Lake McConaughy, are determined by surface-water storage and use policies of the Central Nebraska Public Power and Irrigation District. At the South Platte River study sites, these aspects of toad life are determined largely by Rocky Mountain snow pack. Thus, shoreline physical characteristics have evidently rendered $D$. bufonis locally extinct on Lake McConaughy, possibly through their effects on an intermediate host. Anecdotal evidence and student collections from 1975 to 1979 indicate that the worm did occur in toads from Lake McConaughy prior to the study reported in this paper. Distoichometra bufonis specimens 21042 and 21043, H. W. Manter Laboratory, UN State Museum, were collected from B. woodhousii at Lake McConaughy in 1979.

As a system, the $D$. bufonis/B. woodhousii pair is very similar to the Gyrocotle sp./Chimaera monstrosa system reviewed by Williams et al. (1987) in the sense that the worm populations are not only rather evenly distributed among virtually all demographic classes of the host population, but also evidently subject to infrapopulation regulating mechanisms that inhibit the accumulation of large numbers of parasites. Although infrapopulations of $D$. bufonis are not regulated to the same degree as those of gyro- 
cotylideans, only 10 out of the 477 toads dissected in this study had 25 or more parasites. Thus, the Williams et al. (1987) description of the "general picture" of Gyrocotyle sp. populations as ". . . very high prevalence linked to low intensity ..." applies also to the present study. It remains to be determined, of course, whether such population structures, as opposed to highly overdispersed ones with extreme variations in density and prevalence, are associated with genetically determined parasite traits.

\section{ACKNOWLEDGMENTS}

The authors thank Mr. Darrel Thalken of Roscoe and Mr. Hubert Beal of Brule for access to study sites on personal property, and Scott Frogge, Chris Hakenkamp, Dan Meehan, Gloria Rios, Tim Ruhnke, and Julie Williams for help with fieldwork. The studies were done in facilities of the Cedar Point Biological Station and were supported in part by the Ashton C. Cuckler Fellowship and Harald Holck Award to E.L.H.

\section{LITERATURE CITED}

BAllinger, R. E., AND J. D. LyNCH. 1983. How to know the amphibians and reptiles. William $\mathrm{C}$. Brown and Company, Publishers, Dubuque, Iowa, $229 \mathrm{p}$.

DiAmOND, J. 1986. 1. Overview: Laboratory experiments, field experiments, and natural experiments. In Community ecology, J. Diamond and T. J. Case (eds.). Harper and Row, Publishers, Inc., New York, pp. 3-22.

DiCKeY, L. B. 1921. A new amphibian cestode. Journal of Parasitology 7: 129-136.

Douglas, L. T. 1958. The taxonomy of nematotaeniid cestodes. Journal of Parasitology 44: 261273.

Grimes, L. R., AND G. C. Miller. 1976. Seasonal periodicity of three species of caryophyllaeid cestodes in the creek chubsucker, Erimyzon oblongus (Mitchell), in North Carolina. Journal of Parasitology 62: 434-441.

JANOVY, J., JR., AND E. L. HARdin. 1987. Population dynamics of the parasites in Fundulus zebrinus in the Platte River of Nebraska. Journal of Parasitology 73: 689-696.

JARroll, E. L. 1979. Population biology of Bothriocephalus rarus Thomas (1937) in the red-spotted newt, Notophthalmus viridescens Raf. Parasitology 79: 183-193.

JOYEUX, C. 1924. Recherches sur le cycle evolufif des Cylindrotaenia. Annales de Parasitologie $\mathrm{Hu}-$ maine et Comparee 2: 74-81.

Lemly, D. A., AND G. W. Esch. 1984. Population biology of the trematode Uvulifer ambloplitis (Hughes, 1927) in juvenile bluegill sunfish, $L e$ pomis macrochirus, and largemouth bass, Micropterus salmoides. Journal of Parasitology 70: 466474.

Margolis, L., G. W. Esch, J. C. Holmes, A. M. Kuris, AND G. A. SCHAD. 1982. The use of ecological terms in parasitology (report of an ad hoc committee of the American Society of Parasitologists). Journal of Parasitology 68: 131-133.

PRICE, P. W. 1980. Evolutionary biology of parasites. Princeton University Press, Princeton, New Jersey, $237 \mathrm{p}$.

Prudhoe, S., ANd R. A. Bray. 1982. Platyhelminth parasites of the amphibia. Oxford University Press, Oxford, Great Britain, 217 p.

RigGs, M. R., AND G. W. EsCH. 1987. The suprapopulation dynamics of Bothriocephalus acheilognathi in a North Carolina reservoir: Abundance, dispersion, and prevalence. Journal of Parasitology 73: 877-892.

SoKal, R. R., AND F. J. RohlF. 1981. Biometry. W. H. Freeman and Company, New York, 859 p.

StumpF, I. V. K. 1981/1982. Evolutionary cycle of Cylindrotaenia americana Jewell, 1916 (Cyclophyllidean: Nematotaeniid) in Bufo ictericus Spix, 1824. Acta Biologica Paranaense 10/11: 31-39.

TAYlOR, L. R., I. P. WOIwOD, AND J. N. PERRY. 1978. The density-dependence of spatial behavior and the rarity of randomness. Journal of Animal Ecology 47: 383-406.

Williams, H. H., J. A. Colin, and O. Halvorsen. 1987. Biology of the gyrocotylideans with emphasis on reproduction, population ecology and phylogeny. Parasitology 95: 173-207.

Wright, A. H., AND A. A. Wright. 1949. Handbook of frogs and toads. Vail-Ballous Press, Binghampton, New York, $231 \mathrm{p}$. 